\title{
Money-Bag Politics, Rent-Seeking and Flawed Elections in Nigeria: A Theoretical Statement
}

\author{
Derin Ologbenla, Ph.D \\ Department of Political Science, Faculty of Social Sciences \\ University of Lagos \\ E-mail: derin_ologbenla@yahoo.co.uk, Mobile:08023135433 \\ Waziri Babatunde Adisa \\ Department of Sociology, Faculty of Social Sciences \\ University of Lagos \\ E-mail: adisawazira@yahoo.com, Mobile No: 08027158459
}

Received: February 25, 2012 Accepted: April 18, 2012 DOI: 10.5296/jpag.v2i1.1682

\begin{abstract}
The history of Nigerian politics is replete with money-bag politics. Although, there is hardly any country in the world where instances of bribery or political corruption are not present in their national politics, researches on Africa's postcolonial history, have however shown that, in Africa, corruption is an institutionalized and a systemic practice affecting not only the postcolonial state itself, but also the majority of the citizenry. Using Nigeria, as a case study, this paper argues that since the 1964/1965 Western Region elections to the 2007 general elections, there has hardly been any election conducted in Nigeria without associated cases of corrupt practices such as vote buying, ballot snatching, election rigging, election violence, political and legislative lobbying etc. The aftermath of this or its cumulative effective, is better seen when the number of years spent by Nigeria under the military is weighed against the number of years it spent under civilian administration. Using the peripheral political economy approach, this paper opines that the problem of flawed elections in Nigeria should be traced more to the nature and character of the Nigerian colonial state, prebendal politics among Nigerian politicians, imperial capitalism, primitive accumulation of capital as well as the nature and character of class contestations among various interest groups in contemporary Nigeria. The paper adds that the fierce struggle for state powers and the accompanying prosecution of elections with illicit money, is an indication of the peripheral
\end{abstract}


nature of Nigerian politics.

Key words: Money-bag Politics, Rent-seeking, Elections, Theory, Nigeria

\section{Introduction}

Money and politics are inseparable entities in this modern age of globalization, civilization and imperial capitalism. The reason for this, is not far-fetched. Without money, there can hardly be a smooth transition to a democratic society, or even a fair and equitable political competition in a subsisting democracy. Money is needed by the state and the political actors to finance political activities from time to time. This is why political finance is an integral part of democracy and nation-building(Transparency International, 2004). In actual fact, the type of money we are referring to in this context, is money spent legitimately by political actors to realize their political ambitions and mandates. However, when money is illegally purchased for politics or used wrongly to influence the political outcomes and policy results of a country's political economy, it is then we frown at the relationships between money and politics.

Over the past five decades, experiences have shown that, in most parts of post-colonial Africa, politics is dominated by massive corruption and illegitimate use of money to seize power or capture the apparatus of government. In some instances, this behaviour had scuttled many electoral processes leading to the collapse of apparatus of governance or the political state itself. Money-bag politics is not a new phenomenon in Africa, it is one of the prominent features of the postcolonial African state. Indeed, it is one of the legacies of colonial politics in Africa. Money-bags, contravenes the political values of democracy. In fact, it contravenes what African leaders promised their followers at independence.

On October $1^{\text {st }} 1960$, Nigeria got her political independence from the British after over 100 years of colonial imperialism. Nigerian leaders who wrestled powers from the British promised the citizenry that, attainment of political independence would help Nigerians overcome the challenges of poverty and material deprivation occasioned by colonialism. Attainment of political independence, they insisted, would facilitate economic growth and development, lead to the expansion of the political space and enshrine good governance. The new ruling elites and leaders of Nigeria's independence presented colonial rule in Africa, as an evil, and a tool used by the Europeans to oppress the poor natives( Ekeh, 1975, Mbaku, 2003).

Few years later, most of the dreams of Nigerian citizens at independence were shattered by the ruling elites whom the colonial masters handed over power to. Most of the ruling elites, instead of investing their energy and resources in nation-building, saw the political independence as a golden opportunity of siphoning the resources of the postcolonial Nigerian state thereby causing further bifurcation of the state. Not too long, they turned politics to politics of accumulation usually found in developing societies. By January $15^{\text {th }} 1966$, the political indiscipline and moral decay among the ruling elites had reached its peak such that a 
new class of elites, the military, had to intervene, infiltrate Nigerian politics, and eventually disrupt the young democracy in the country. Consequently, the Nigeria state was left to suffer serious setbacks from successive military interregnum which lasted for over twenty nine years. In the process, the Nigerian economy ran into different kinds of crises, at times mild and at times so severe that the burdens on the masses were often unbearable. As a result of this development, coupled with the nature and character of the Nigerian state, politics became a theater primitive capital accumulation. It became a war that each emerging class was struggling to win. Political competition was characterized by intensive use of money to influence the choices of the electorates, and policy outcomes (Mbaku, 1996; 2000; Ake, 2000).

Fifty years after Nigeria's independence, corruption is still pervasive in our national life with the attendant losses to the nation and the poor masses. Indonesia and Malaysia with whom Nigeria had similar colonial and post-colonial history are making huge progress. Indonesia is one of the fastest growing economies in the world today(Cunliffe-Jones, 2010:17). The reverse is the case of Nigeria. Virtually all the sectors of the Nigerian economy are embodied in the problem of corruption. Most pathetic is the problem of political corruption which has continued to threaten the cooperate co-existence of the nation. It is however shocking, that, despite the avalanche of national and international efforts at combating corruption in the public and private sectors of the Nigerian economy, nothing significant seems to have changed. The political class is still heavily involved in corrupt enrichments, civil servants whose jobs are to manage the nation's economy and state apparatuses behave as if they are in government's jobs for their personal enrichments, the same story can also be said about the nation's judiciary that is gradually being pulled into the stream of corruption(TELL Magazine, October 4, 2010: 2). The objective of this paper is to provide a lucid theoretical analysis of the relationships between 'money-bag politics', 'rent-seeking' and 'flawed elections' in contemporary Nigeria especially since 1999. The paper is divided into five sections. The first part examines the concepts of corruption, rent-seeking and money-bag politics. The second part looks at the interplay between corruption, money-bag politics, rent-seeking and flawed elections. Part three of the paper takes a critical look at the different theories of elections but concludes on the peripheral political economy theory as one of the most suitable theories for explaining the contradictions caused by money-bag politics. Part four cites examples of corruption in flawed elections in Nigeria while the last section concludes the paper.

\section{Corruption, Rent-Seeking And Money-Bag Politics: A Diagnosis}

Corruption has remained a major obstacle to sustainable development most of parts of the world especially in the developing countries. The reason for this is not far-fetched. Corruption drains the resources that ordinarily should have been used to prosecute development programmes for the poor and the vulnerable groups, and divert such money into the coffers of the rich while the poor are subsequently languishing in abject poverty. Despite its damaging effects on both the developed and developing countries of the world, there has not been a consensus opinion on its meanings. This is one area where the development practitioners have found it difficult to do a proper diagnosis of what corruption means across 
cultures, to study it, theorize about it, historicize it as well as develop suitable methodologies that are capable of revealing the actual experiences of the citizenry suffering from corruption or affected by the phenomenon(Kaufman and Dininio, 2006; World Bank 2008: 2-10).

In the same vein, the dependency scholars like Ekeh(1975) and Ake(1996) have argued that the historical context within which corruption grew in Western societies were and are quite different from that of Africa. Thus, it would be difficult to adopt Western definitions of corruption wholeheartedly for the study of corruption in African societies considering the peculiar cultural and historical differences between the two continents. Notwithstanding all the contending arguments, corruption has always been defined and linked to the performance of public office, citizenship, and public interests. The World Bank had in 1997 defined corruption as the abuse of public power for private gains. But the question that many scholars have chosen to ask is, how do we distinguish a public power from a private interest. Ekeh(1975) provided a lucid explanation for this, using citizenship as a unifying construct between the public and the private sphere. The public is a similitude of the civic public- this is a place where citizens of a country are expected to performance certain constitutional roles and responsibilities or duties to their country in anticipation of enjoying certain rights. In a civic public, every citizen is expected to protect the interests of the public by adhering strictly to public service rules and regulations. As an employee of the government, it is expected that public funds or positions of authourity are jealously managed without any form of fear or favour. Corruption ensues when a citizen tries to influence the outcomes of the public affairs, events, contracts using monetary or pecuniary affluence. Corruption is therefore linked to the performance of public duties. It is therefore morally reprehensible for a citizen, whether in government or outside to attempt or even influenced the decision of the government on a particular public issue or misappropriate funds meant for the public. This is why corruption is usually defined as the abuse of public office for private gains(Kaufman and Dininio, 2006; Pinto-Duschinsky, 2006).

Corruption entails the use of money to influence the decisions of the government on the economy, politics, education, law, etc. Corruption also connotes the extraction of bribes from the citizens by public servants or political office holders with a promise that the outcomes of public policy would be thwarted. Because the effects of corruption are not only on the minority that usually carry it out, but the majority of the people who did not even have knowledge of the corrupt practices, the political state is usually urged to minimize rooms for opportunism as well as uproot the foundations of the cankerworm in the state(Odekunle, 1986; Mbaku, 2000; Nnorom and Adisa, 2010).

Rent-seeking is a grandchild of corruption. It is indeed, a subset of corruption. While corruption encompasses all activities surrounding the abuse of public office for private gains such as embezzlement of public funds, contract inflation and misappropriation of public funds, rent-seeking is about expending resources in an attempt to influence the outcomes of public policy. Rent-seeking includes lobbying to influence the decisions of the government on an election outcome or election's legislations with the anticipation that if such pressure succeeds, the political result would be favourable to one's political or class interest. 
Rent-seeking also entails the bribing of civil servants with whom is the responsibility to conduct elections, manage the nation's electoral process and ensure that transparent competition among the existing political interest groups(Bushanan, 1980; Wenders, 1987; Wiseman, 1990; Mbaku, 1992). The use of political violence to intimidate the government or the opposition is also regarded as a rent-seeking behaviour( see Mbaku, 2000). The degree to which a nation witnesses rent-seeking in its political process is relative to the level of development of the country, the nature and character of the state, and the degree of at which the rule of law prevails in the state.

"Money-Bag Politics" is a form of rent-seeking. It entails the use of money illegitimately to influence the outcomes of an electoral or a political process. In fact, money-bag politics has to do largely with rent-seeking in political finance. Money that is used generally to prosecute an election is called "political money". However, someone may misuse the money or even use its personal money to influence the interests of the electorates or the civil servants, when this happens, the politician is said to have engaged in "'money-bag politics" ( Hoddes, 2003; Walecki, 2003; Pfeiffer, 2003; Arahano, 2003; Adetula, 2003; Transparency International, 2003). Money-bag politics is the illegitimate use of money by a group of persons with either political or economic motives to influence the outcomes of an election usually by paying the electorates some petty cash, buying the conscience of party members or opposition members. The history of money-bag politics in Nigerian politics can be traced back to the development of the Nigerian state and its political process. This is what we shall turn to in the next section.

\section{Money-Bag Politics And Rent-Seeking In The Development Of Nigerian Politics}

The history of Nigerian politics can be traced back to the colonial days. Both the Nigerian state and Nigerian politics developed out of colonial imperialism. According to Mabogunje(1967), the history of the Nigerian colonial state actually dated back to 1861 when Lagos was ceded to the British Empire. However, it is important to note that building of and concretization of nationalism did not come until 1900 when the Northern and Southern Protectorates were amalgamated into a polity. In 1914, the Nigerian colonial state was born courtesy of British colonialism. The colonial masters introduced their new system of administrations into the different parts of the country. Colonial bureaucracy grew in number as the powers and the hegemony of the Nigerian colonial state grew. Constitutional development also followed suit but limited political participation for the natives. The colonial masters, throughout their time as political overlords, bifurcated the Nigerian colonial state, created discords and divisions among the existing tribal and ethnic groups in order to promote the economic interests of Europeans. It introduced a new mode of production that was favourable to industrial capitalism. Cash crops from Nigeria and the rest of Africa were exported to Europe in abundance. In the process, the colonial state created different classes, where none existed in pre-colonial days. It would be remembered that before the introduction of colonialism into Africa, most African people lived communitarian and egalitarian life. The production of goods was primarily to motivated by the need to fulfill the immediate needs of the family and the community at large. There was no direct influence 
of industrial capitalism. As a result of the introduction of colonialism, capital became a commodity to be sold in the market. A money market economy was superimposed on the existing peasant economy. The natives in the process became alienated(Ake, 1981, Mamdani, 2004).

To be able to meet the demands of capitalism in Europe as well as in Africa, the colonial masters had to introduce modern politics into the political lifestyles of indigenous Africans. Both the ownership of the political state and its resources were no longer within the locus of the community, it became the private property of the colonial state, and the foreign bourgeois class. As a matter of necessity and as a result of the Indirect Rule System it had adopted, the British felt that without the connivance of the Native Rulers, on one hand and on the other hand, the few opportunistic educated Africans, colonialism cannot succeed, it therefore embarked on massive collaboration of these two classes. In the first instance, it recognized the powers of the traditional rulers in the administration of the colonial state but with modern modification. Later, it saw the need to integrate the few educated Africans into the political space, as a matter of necessity. These were the two classes that originally joined the foreigners in building the Nigerian colonial state. Until 1954, when the Federal Constitution came into existence, the political powers enjoyed by the Natives were indeed very limited especially the educated Nigerians whom the colonial masters saw as their enemies. Because the colonial state itself could not be completely divulged of instances of corruption, it directly or indirectly taught the emerging political and economic classes how to steal government's money for their own use.

\section{Post-Independence Experience and Money-Bag Politics In Nigeria}

The attainment of political independence by Nigeria which was originally conceived and sold to the citizenry by the ruling elites as an opportunity to transform the postcolonial Nigerian society after over 100 years of colonial imperialism, did not bring the much awaited development. As stated earlier, instead of resulting in massive transformation of the Nigerian society, post-colonialism simply meant imperialism. Ake(2000) provided a detailed analysis of the situation this way:

Colonialism gave Africa a legacy of a state which had near-absolute control of society, polity and economy and yet remained the private property of the rulers. By virtue of being appropriated by particular interests instead of rising above all interests in society, this state negates the very essence of the state and its civilizing element namely its 'relative autonomy'. It could not express the corporate identity of its subjects or engender it. It could not effectively mediate a social conflict between the contending private interests because it is also a private interest. Far from mediating conflict, it became a theatre of war, a war for the appropriation of its vast power resources(Ake, 2000:91). 
Ake continues that:

Like the state, politics in much of post-colonial Africa tendentially negates its essence. For instead of being the occasion in which disparate interests are aggregated to define common interests and to pursue collective goals, politics is perverted into a relentless war of all against all. As politics degenerates into warfare, it also throws up governmental forms and leaders appropriate to its character, hence the high incidence of military and authouritarian rule. The consequences of this for economic development in Africa have been disastrous. To begin with, it means that there is no national community, only groups competing to capture and appropriate the state. That condition virtually nullifies any prospect of evolving and carrying through a national project; including development. Where attempts are made to seek development, policies tend to be hampered by social and political contradictions such as the divorce of public policy from social needs. The lawless struggle for power by those who control the state against other interests leads to endemic political instability which has been highly detrimental to economic development(Ake, 2000:91).

As explained by Claude Ake in the above rendition; the coming of independence did not change the character of the post-colonial state in Africa but most importantly, it changed the composition of the managers of the state. At independence, three dominant classes seemed to be much more dominant at the corridors of powers using money to seduce the electorates- (i) The Nationalist Leaders who also doubled as leaders of the dominant political parties. (ii) Foreign Bourgeois class (iii) Comprador Bourgeoisie. Although, all these classes were indeed working together for the same goal, the Nationalist leaders seemed to have benefitted largely from the prevailing money-bag politics and corruption in public life. This development did not become so glaring until the time of the general election of 1983 which was marred by massive rigging, bribery, rent-seeking and corruption. In order to bring out the historical linkage of this crisis of development with electioneering process in Nigeria, the next section shall be discussing election and electioneering processes in colonial and post-colonial Nigeria.

\section{Elections and Electioneering: A Critical Appraisal}

\subsection{What is an election?}

Election has been variously defined by different authors. It has been defined as the meaningful and extensive competition among individuals and organized groups (especially political parties), either directly or indirectly for the major positions of governmental power, a highly inclusive' level of political participation in the selection of leaders and policies through regular and fair elections. Iyayi Festus (2007).

From the above definition, can there be an election without competition? If all contestants in an election withdraw and the only surviving candidate is returned unopposed, can there be said to be an election? Two other important points to be noted are the regularity and fairness of elections. If elections are not periodic, but a "once and for all event", can there be said to 
be election? This brings us to the aspect of democratic governance. In any democratic dispensation, the tenure of political office holder must have a fixed period. The American Presidential System being practiced by Nigeria prescribes four year tenure for the office of the President, Governors and members of the Legislative Houses at the Federal and State levels. Another pertinent question is whether elections that do not satisfy the basic ingredients by following all laid down rules and regulations leading to the conduct of the election can be regarded as election in the first place. It is necessary to state that before the conduct of any election, there must be set of rules to regulate its conduct and non-adherence to such rules could invalidate the entire exercise. Arrow (1963) said that an election is a formal decision-making process by which a population chooses an individual to hold public office.

Election has been a potent tool or mechanism by which modern representative democracies operate in choosing leaders. In any political organizational structure, the leadership continuun is always pyramidal, and so the vacancies up there are always limited. In most cases, there is always one vacant position. Whether it is the office of President, Governor, Constituency/Senatorial representative, only one person would be expected to be there at a time. This is why the competition for such position is always competitive, and in some cases, some contestants go extra miles to embark on actions that may be inconsistent with the rules governing the conduct of the exercise.

The global adoption of elections as a basis for selecting representatives in modern times is sharply in contrast with what use to be the norm in medieval ancient Athens, where elections were regarded as the exclusive preserve of the Oligarchs, who fill most public offices by using allotment in chosen office holders. However, lyayi (2007) posits that

Elections provide the medium, by which the different interest groups within the bourgeois nation-state can stake and resolve their claims to power through peaceful means. Election therefore determines the manner and methods by which changes in the bourgeois social order may be brought about.

Okoye (2003) says that election is

a formal act of collective decision that occurs in a stream of connected antecedents and subsequent behaviour. It involves the participation of the people in the act of electing their leaders and their own participation in governance. ...It encompasses activities before, during and after elections,

From the foregoing, election is therefore the process of choosing a person to fill an office or membership of a society or decide an issue by people eligible to cast ballots. This may be by uplifted hands or by voice or by casting of ballots. The winner is the one who has the most votes. Based on the rules guiding the conduct of such election, unless breached or circumvented, the outcome is expected to be respected and accepted by all those who subscribe to it as a means of either choosing a leader or deciding an issue. 


\subsection{Types of Elections}

There are many types as well as varieties of elections, depending on the system being adopted by a political entity. We shall examine the following types of election:

\subsubsection{Direct and Indirect Election}

Direct election involves individuals in the society participating in the process of selecting leaders. This was the prevalent method in ancient Greek City States where adult male citizens choose their leaders. However, the system precludes women and slaves. As society grows, the system became very unwieldy and this gave way for Indirect Election. According to Ujo, it is a method whereby there is more than one vote or decision separating the individual voter from the collective outcome. Ujo went further to give example of the American System as a classical case, whereby the US President is elected by an Electoral College, which is composed of electors equal to the whole number of Senators and Representatives to which the state may be entitled in congress.

This is why a candidate who scores the highest popular votes may be denied victory if he fails to secure the required Electoral College vote. A small group therefore determines the winner at the expense of majority of the people.

\subsubsection{Open and Secret Ballot}

As the name connotes, an open ballot is one where the electorates vote openly. This may be by raising-up of hands or queuing openly behind preferred candidates. The beauty of this system is that results could be arrived at on the spot. In terms of producing ballot papers, boxes and other balloting instruments, the system is very cheap. Ujo in quoting Mill (1910) and Pitkin (1967) said that the "system allows for accountability and commitment" and went further to state that if we wish to hold people accountable for the way in which they cast their vote, we obviously need to know how it has been cast.

He posited that the argument for commitment of an electorate is based on the fact that when an electorate decides to cast a vote in favour of a particular party platform, he expresses a preference for the package of policies over any other package and by implication legitimizes its implementation.

Despite some of its attractiveness, the open ballot system has been criticized as it could lead to unintended problems, violence, corruption and disenfranchisement.

However in order to maintain the sanctity and secrecy of the electorate, the secret ballot system becomes an option. The system makes it possible for someone to vote for his preferred candidates in secret. The voter may keep such decision personal to himself.

In between the two systems, there is the modified open ballot system, whereby electorates are 
accredited openly but allowed to vote secretly by keeping the choice of candidates or parties they voted for to themselves.

\subsubsection{General Election}

This type of election takes place in a fixed period. All registered or accredited political parties field candidates to contest elective positions. In some environments, independent candidates, who do not belong to any political party, may also, be afforded the opportunity of contesting for elective posts. In Nigeria, the 1999 Constitution specifies that elections are to hold once in four years and registered political parties are free to sponsor candidates, provided such candidates fulfill the constitutional and legal requirements. The constitution does not make room for independent candidates.

\subsubsection{Bye-Election}

Bye-election is conducted to fill vacancies necessitated by death or resignation of a candidate. The winner of such bye-election would be expected to represent his constituency for the remaining period.

\subsubsection{Recall Election}

At any time that constituents are dissatisfied with the performance of their representatives, they may decide to recall such candidate to allow for another election to be conducted. Sections (69 \& 110 of the 1999 Constitution) spelt out the conditions for the recall of a member of the Senate and House of Representatives at the Federal level and House of Assembly at the State level. The conditions include a petition presented to the Chairman of the Independent National electoral commission signed by more than one-half of the persons registered to vote in the Member's Constituency alleging loss of confidence in the member. The processes as contained in subsection (B) states that

the petition is thereafter in a referendum conducted by the Independent National Electoral Commission within ninety days of the date of the receipt of the petition, approved by a simple majority of the votes of the persons registered to vote in that member's constituency.

Although a number of constituencies have threatened some of their representatives in the past, no recall process has been successful in Nigeria.

\subsubsection{Run-Off Election}

This type of election is conducted for the two front runners in an election that could not produce a clear winner. For instance, the Nigerian electoral laws stipulate that for a candidate to be elected President or Governor, apart from scoring the majority of votes cast, the candidate must also secure one-third of the votes cast in two-thirds of all the states of the Federation or Local Governments in the state. If any candidate is unable to meet those 
conditions, the two candidates that score the highest votes are made to face a run off election. Sections 134(4) and 179(4) of the 1999 Constitution make provisions for Run-off Election.

\subsubsection{Re-Run Election}

This is the creation of the judiciary, based on petitions determined from the 2007 Elections. The Election Petition Tribunals or Appeal Courts, on determining the impropriety of elections to the office of Governor or any of the legislative Houses, order re-run elections in the state/constituency or parts thereof.

\subsubsection{Referendum}

Referendum is a type of election whereby voters are expected to vote for a specific item or policy by indicating YES or NO. The 1999 Constitution spoke about conducting a referendum for the recall of a member. In producing such ballot paper for the exercise, constituents will be expected to vote YES or NO for the exercise.

\subsubsection{Hung Election}

This is a type of elections that produces no clean winner, especially in a parliamentary system of government, where political parties are expected to meet certain conditions before forming a government. If the election becomes inconclusive for a party to form a government, two or more political parties can form a government.

\subsection{Brief History of Elections in Nigeria}

Nigeria at different times had conducted elections for the recruitment of persons to control Governmental machinery. These elections have not been smooth sailing, as they were dogged by one problem or the other. For the purpose of this exercise, it may be necessary to categorize these elections into the following:

\section{Elections before Independence}

\section{Elections Immediately After Independence}

\section{Military Regime Supervised Elections}

\section{Civilian Administration Supervised Elections}

\subsubsection{Pre-Independence Elections}

The first elections to be conducted in Nigeria were limited to legislative Councils in Lagos and Calabar in 1922. This was followed by elections of 1951 as reported by Okonjo (1974). The next set of elections was the one that ushered Nigeria into independence held between 1958 and 1959. 


\subsubsection{Elections Immediately After Independence}

Three sets of elections were held in Nigeria between 1960 and 1965. The first of such election was conducted in the newly created Midwest Region in February 1964. In December of that same year, Federal elections were held nationwide, while regional elections took place in 1965. lyayi noted that both the Federal and Regional elections were extremely controversial. Quoting Adegboyega (1981:19) lyayi (2008) said that

the elections of December 1964 turned out to be a farce. It was completely boycotted in the Eastern Region, where the NCNC Government used its powers to ensure that no election was held. It was also partly boycotted in the West, North, Midwest and Lagos, with the effect that the election results lacked credit and were nationally unacceptable. However, while the UPGA rejected them, the NPC and its allies of the NNA, which singled handedly carried out the elections, accepted them. There followed a National Stalemate.

Adegboyega (1981) also put the controversy that trailed the 1965 election more succinctly when he said that In very many cases, candidates who held certificates that they were duly elected in their constituencies later heard their names mentioned as defeated candidates through governmental news media.

\subsubsection{Military Regime Supervised Elections}

When Murtala Mohammed assumed the leadership of the country in 1975, his administration promised to hand over power to civilian government in 1979. His death in February 1976 did not deter his successor, General Olusegun Obasanjo from properly executing a transition programme that culminated in the conduct of elections that ushered in the government of Alhaji Shehu Shagari on 1st October, 1979. The Military under General

Ibrahim Babangida also conducted elections into Legislative Houses at both Federal and State level, as well as Governorship elections in 1992. However, as observed by lyayi (2007), the elections

were frequently delayed, cancelled, postponed and adjusted to produce a result predetermined by the military. In the event that this did not happened, the results of the June 12, 1993 Presidential elections were criminally and brazenly annulled by General Ibrahim Babangida on the excuse that the military was uncomfortable with them

Upon assumption of office as Head of State following the death of General Sani Abacha, General Abdulsalam Abubakar kick-started a Transition programme leading to the 1999 elections that produced Chief Olusegun Obasanjo as President. Nigerians were eager to join the league of democratic nations and so were not so interested about the imperfections of the elections. 


\subsubsection{Civilian Administrations Supervised Elections}

The first election conducted by civilian administration was in 1983. The outcome of the election^ that returned Alhaji Shehu Shagari for another four years was considered as not too healthy. In the elections, the NPN controlled government was alleged to have perpetrated all sorts of electoral malpractices. Apart from conducting the 2003 general elections which was adjudged to have been rigged by the ruling POP, the civilian government also conducted 2004 Local Government elections. It should also be noted that the States Independent Electoral Commissions have been in charge of elections at the Local Government level in line with the provisions of the 1999 Constitution. The civilian also conducted the 2007 general elections. Although the elections were said to fall short of the basic standards of normal election according to reports of observers, it however recorded a feat in Nigerian electoral history. It would be the first time that civilian will conduct elections to transit power from one civilian personality to another. For the first time as well, a number of elections both for governors, Senate, House of Representatives and House of Assembly were nullified by the judiciary. This contributed substantially to the belief that the elections were not well conducted.

\section{Theories of Money-Bag Politics and Elections in Nigeria}

Elections, by their very nature, are founded on some profound theories, and it is necessary to examine two of these theories. This paper is anchored on the Political Economy Approach.

\subsection{Modernization Theory}

The modernization theory is a theory of development and politics. Modernization theory premised its thesis on the dichotomy between the development of the advanced capitalist nations and the developing societies. The theory argues development does not come like a magic, it has to evolve over a period of time with feasible changes in the structures of society, science and technology, organization of government, the nature and character of political institutions and practices and the prevailing value system. Modern societies, according to its advocates, have universalistic values that do promote development and sustainable democracy(see Smith, 2003). Institutions of government including civil bureaucracies are operated on universal norms and standards, so also is politics and nation-building.

The building of a nation, in developed societies, is also premised on the building of modern values that will promote fair competition, equity and justice. The rule of law is paramount is paramount to the development of a nation's politics, since law, if adhered to, will protect both the leaders and the led(Eisenstaedt, 1966). Proponents of the modernization theory argued that the purpose of an election in a civil democracy is to elect responsible leaders who can stir the ship of the nation. Both party politics and vote casting are rooted in universalistic values. In sum, the modernization theory believes human societies will go always go through series of developmental stages, from a state of tradition to modernity.

It is on the basis of this, that it argued that politics in the developing societies a reflection of 
the stage of development of the society, and the prevailing value systems in those societies. Developing societies, according Smith(2003) and Mungiu-pippidi(2006) operate largely on patrimonialism and particularism. It is believed that those developing societies are corrupt, are influenced by the presence of culture of patrimonialism. No wonder, politics is rooted more in tradition, ethnicity, favouritism and pre-bendalism. Wherever prebendal politics prevails, bribery and exchange of money for electoral compensation is nothing but one's commitment to its ethno-religious group. State is captured to re-emphasized the supremacy of one's ethnic nationality. Thus, it is therefore incumbent on members of particular interest or ethnic groups to help buy votes and rig elections. As suitable as this theory is, it overlooks the evil effects of capitalism, the individual differences of candidates standing for elective positions, the role of history in the making of a nation. These are the vacuums other theories intend to fill subsequently.

\subsection{The Public Choice Approach: Its Efficacy In Nigeria}

The Public Choice Approach is an economic theory of corruption and public policy including elections. To Mbaku(2000), the theory is simply the application of economic theory to the study of politics. This holds that the viability of a public policy or political processes in a country is relative to the nature of government's intervention in voluntary exchange and the behaviour of bureaucrats. According to Mbaku(2000), the design of rules to regulate socio-political relations and the functioning of these rules is affected by the activities of individual political actors within the country including the legislators that make the laws, and the civil bureaucrats that are to implement them. Mabku posited further that, the public choice approach emphasizes several issues that are very important to public policy and good governance in a country. First, individuals usually find it efficient and convenient to accept the rules governing socio-political relations. Second, these rules form the foundation for the social arrangements within which these individuals will interact and make choices. Thus, the outcomes of rules are determined by the nature of rules bureaucrats and politicians choose to accept.

The public choice approach argues that there is a relationship between the nature of rules in a society, the growth of institutions of governance and the behaviour of bureaucrats. When the rules of behaviour in a polity are not enforced by the state, interest groups are likely to subvert social relationships, and usurp the loopholes for their own selfish interests. Too much involvement of the government in the regulation of a market economy may give the civil servants the opportunity to exploit the entrepreneurs and the political actors seeking government's favour or wanting to capture power. When civil servants realize that government's control over the nation's economy is too totalistic, they may in the process impose undue rents on people in need of one form of government's service or the other. Mbaku(2000) argues that bureaucratic corruption of which rent-seeking and money-bag politics belong to, is an opportunistic phenomenon. If corruption, rent-seeking and money-bag politics are to be curbed, then, laws must be enforceable in courts, and the political space must be democratize such that incumbent governments take the advantage of its incumbency over the other political parties. It is however, important to note that the public 
choice approach is insufficient for the explanation of the relationship between the advanced political economies and the immanent contradictions of underdevelopment in Africa. How can we the accumulative character of the ruling elites in Africa? What explanations do we have for the nature and character of the Nigerian peripheral political economy? How has this determined the emerging classes in Nigeria, and their political behaviour? This vacuum left by the public choice theory has effectively been covered by the peripheral political economies advanced by Claude Ake and a lot of the dependency theorists like Franz Fanon, Samir Amir, Andrew Gunder Frank etc.

\subsection{The Peripheral Political Economy Theory Of Elections In Nigeria}

The peripheral political economy is a theory of development and politics which seeks to explain the underlying factors in the underdevelopment of African colonial and postcolonial societies using the Marxist political economy constructs. It is both a theory and an approach to the study of the contradictions engendered by forces of imperialism in Africa. The theory simply holds that a good analysis of African development process cannot be divulged from Africa's political economy history. The approach takes historical materialism as its methodology. The political economy holds that for you to understand the intricacies of African politics, you must trace the dynamics of industrial capitalism in Africa, the colonial legacy, the changing mode of production, the economic base of African political elites, the conspiracy between domestic capital and the foreign capital, the changing character of the civil bureaucrats, the accumulative pattern of the ruling elites and the dominant political and economic classes, the invisible hands of the global powers in the regulations of African politics, the peripheral nature of African economies, the long years of militarization of governance and the changing ideologies of the political class, the leadership crises, the response pattern of the masses and the civil society to the misrule of their leaders, the impending embers of revolutions in Africa and the response of the postcolonial state, the viability of political institutions and future of democracy as a tool of development in a peripheral economy(see Inhovbere, 1989; Onimode, 1989; Ake, 1996; 2000; Adisa, 2010).

Some of these issues shall be examined seria tim especially as they relate to the dynamics of electioneering in Nigeria. The peripheral political economy holds Africa is a peripheral political economy, and thus, pre-bendal politics is one of its dominant characteristics. As a peripheral economy, the dominant economic class is the foreign bourgeois class. The reason for this, is not far fetched. One, without excessive exportation of raw materials to Europe, and dependency on foreign capital, the peripheral economy cannot grow. This is partly because the domestic lacks the productive capacity to be able to match the developed nations. Second, the economic base of the ruling elites is weak. The state too cannot survive own its without dependence on foreign nations. It borrows loans and fixes the prices of its goods based on the workings of the global political economy(Ake, 1981; O'Bren and Williams, 2004). Even the determination of the nature of goods for production and exchange is largely is a function of foreign capital. This indeed, is the glaring picture neo-imperialism holding the future of development in Africa backward It contradicts the basic tenet of development which is freedom. 
Ensuing from this, is the battle to either disengage the peripheral state from long years of imperialism. If we disengage can we survive?. How viable is our economic class? These are some of the questions being asked by the dominant political actors. They are between the devil and the red sea. Of course, they cannot disengage from the crises of imperialism, reason being that, they lack the productive capacity to stir the development of their nations. Many of them rely on the state for their living. They wholesomely depend on captured powers in order to survive. At times they will connive with the other classes including the foreign bourgeois class to prosecute elections. Thus, politics is seen more as an opportunity to either gain economic power or consolidate the existing ones. As Marx puts, existence proceeds essence. Man must work before he can eat. Thus, the quest for wealth and economic survival is usually the primary motive behind both the political campaigns and struggles to win an election. The rule governing politics and political competition in this type of a state, is the rule of business- emphasis on survival and not sportsmanship. Ake in Inhovbere(1989) has this to say about the nature of the state in Africa, and politics is a mere a game for primitive accumulation. According to him:

The states of postcolonial Africa have very limited autonomy, particularly from the hegemonic social classes and are immersed in class struggle. This limited autonomization reflects the limited development of the productive forces especially in so far as they hampered the generalization of commodity production and exchange. We may interpret the limited autonomization as meaning that the state in Africa is rudimentary since autonomization is the unique quality of domination in question. Some may prefer to look at it as a deformity since further development has been stalled for so long. No matter, what needs to be kept in view is that limited autonomization means that the Africa state hampers the realization of the law of value and the development of the productive forces. It hampers them because it is in no position to mediate the conflict between social capital and particular capitals. The development of the state within the social formation remains at a level not much higher than the stage of primitive accumulation, with massive intervention of force in the labour process at the detriment of the realization of the law of value. The state in postcolonial Africa is unable to mediate the struggle between the classes and even within classes particularly the hegemonic class. The net effect of this is that politics, essentially the struggle for the control and use of state power becomes warfare. Power is overvalued and security lies only in getting more and more power. There is hardly any restraint on the means of acquiring power, holding it or using it. Might is co-extensive with right. So the subordinate classes who have little power and are not really a constitutive social force in the state have no rights and their interests hardly feature in the formation of public policy, a fact which helps to explain why the policies device in the name of development are quite irrelevant to actual development(Ake in Inhovbere, 1989:45).

Going by the above rendition, it sufficed to say that the peripheral political economy is a very good theory for the explanation of the present crises confronting elections and electioneering in Nigeria. We need not ask why elections are usually turbulent when the contradictions of industrial capitalism have not been overcome in the country. The efficacy of this shall become more clearer as we proceed to discuss the linkages between money-bag politics, 
rent-seeking and flawed elections in Nigeria.

\section{Money-Bag Politics, Rent-Seeking and Flawed Elections In Nigeria}

In this section, we shall be explaining the theoretical link between the existence of or otherwise the prevalence of money-bag politics and the possibility of flawed elections. A flawed election is an election that has been voided by a competent court of law usually an electoral tribunal following the stipulated guidelines in an Electoral Act. Since the time of Nigeria's independence, many elections have been voided by election tribunals but we shall be making reference to recent voided elections i.e 2007-2010.

Which events usually take place before an election is voided? It is important this question is addressed before we proceed. For sure, there are usually pre-election activities- campaigns, political mobilization through the media and posters. In addition, citizens have to register and vote on the day of elections. Most importantly, political parties must have been formed before any form of election takes place so that citizens can make their choices out many ideological strands already in the country. In these activities, all the political actors will either play active or passive role. One, an election has to be funded and financed. Parties may get financial supports for their finances. For instance Section 228(c ) of the1999 Constitution gives power to the National Assembly to provide for an annual grant to the Independent National Electoral Commission(INEC) for disbursement to political parties. In line with Electoral Act 2002, Section80(2 ) (b), INEC disbursed the total sum of \#420 million to 7 political parties namely- Alliance for Democracy(AD), All Nigeria's People's Party(ANPP), People's Democratic Party(PDP), All Progressive Grand Alliance(APGA), National Democratic Party(NDP), People's Redemption Party(PRP), and United Nigeria People's Party(UNPP). The 2006 Electoral Act also made provisions for the state to finance existing political parties(see Adetula, 2003: 21). The current 2010 Electoral Act also mandates INEC to make provisions for the finances of existing political parties. But the irony of it, is that most political parties in Nigeria especially the dominant political parties depend largely on what money from friends, political associates as well as rents from entrepreneurs who may be willing to seek government's favour after the elections.

Party finances may also come from the Mafia groups who have been at the corridors of powers for several years and may not be willing to relinquish state control to any opposition groups. In this case, civil servants may readily come as their connivance. In Nigeria, rent-seeking has been a combination of the members of the political class, the civil bureaucrats and the few business entrepreneurs. Thus, the use of money to buy favours from the government has been widely distributed among these groups including their kins who are able remain at the corridor of power(Joseph, 1995; Mbaku, 2000). Vote buying a major characteristic of most politicians in the developing countries(Pfeiffer, 2004). During elections, politicians are out not to impress the people with their manifestos but to give them petty cash in order to buy their interest. In some instances, food items may be given out unsolicited for by the politicians. Political thugs also help to ensure compliance where law enforcement is weak or security of lives and property is nothing to write home about. 
The problem of money-bag politics reached its crescendo in the 1980s, and 1990s when the Nigerian economic crisis that started in the late 1970s had culminated into many problems of development. Crushing economic conditions coupled with the increasing pauperization of the working had heightened the various national crises that emerged. Even the middle class was fast crushing with their prestigious and enviable position. This development also affected the commitment to national development. In the midst of these crises, Nigeria began to witness corruption explosion feasible in the emerging nature of bureaucratic corruption. As events turned out to be, corruption in Nigerian politics assumed an alarming proportion. Most civil servants whose responsibility was to ensure that public institutions discharge their constitutional obligations without fear or favour, turned such institutions into instruments of plunder. This crisis ultimately moved Nigerian politics into an age of "Ghana Must Go". Rent-seeking is a pervasive characteristic of African politics and it is indeed efficacious in Africa's contemporary history as clearly demonstrated by John Mbaku in his book "'Bureaucratic and Political Corruption in Africa: The Public Choice Perspective".

Mbaku posited further that politicians seeking elective positions may deliberately mobilize campaign contributions from interest groups who are prepared to sponsor their political programmes in anticipation of favourable political and economic conditions such as monopoly over importation of goods, tax waiver etc. Interest groups may also lobby legislators or law-makers to make special legislations that will create rents and improve their ability to extract rents from the economy. This is why, business tycoons may afford to expend much money on the campaign programmes of incumbents so that when such politicians win for the second time, their business interests will be protected by the state(Adisa, 2010). Instances of these descriptions aptly made by Mbaku, are reminiscent in Nigeria's general and run-off elections. Three case studies shall be cited here to buttress our analysis so far. Two from the South-West and One from the East.

\section{Case Study 1: The Flawed Election Of Olagunsoye Oyinlola Of Osun State}

The Appeal Court sitting in Ibadan had set aside the judgment of Election Petitions Tribunals which initially gave Governor Olagunsoye Oyinlola victory. The victory was set aside on the basis of the fact that the tribunal erred in law by not judging the case on its merits. Prior to this, there had been allegations of lobbying between the tribunal judge and Olagunsoye's counsel. Though, yet to be fully investigated, the exchange of telephone conversations between the two duos was regarded as a form of judicial corruption. This was a form of rent-seeking earlier discussed. In this case, many of the votes cast in 10 local governments out 31 local governments in the state

\section{Case Study 2: The Flawed Election Of Governor Olusegun Agagu Of Ondo State}

The Labour Party was reported to have got its victory from the way and manner the election of Governot Olusegun Agagu was marred by corruption, rent-seeking, money-bag politics and rigging. During the elections of the flawed, it was reported that there were instances of multiple voting occasioned by heavy bribery of party agents and INEC officials(Nigerian 
Compass, Wednesday Feb. 25, 2009).

\section{Case Study 3: The Flawed Election Of Governor Iduaghan Of Delta State}

Iduaghan's first election was said to have been marred by massive rigging in the cancelled voided votes. Aside from, electorates who had left their homes to vote were reported to have been either been attacked by thugs or intimidated by hungry-looking youths. The use of thurggery and force in an election is contrary to the provision of the Electoral Act, and is indeed a form rent-seeking. Aside from these cases of money-bag politics and flawed elections in Nigeria, we present in the appendix Transparency International's ranking of countries in terms of their vulnerability to political corruption. In addition to this, the next section sheds more light on the theoretical linkage between money-bag politics, the problem of god fatherism and flawed elections in Nigeria.

\section{Money-Bag Politics, God-Fatherism, Patron Clientism and Flawed Elections in Nigeria}

In most parts of Africa, the phenomenon of money-bag politics has been thriving with some connivance of political behaviours typical of a developing society; one of which is the problem of god-fatherism. God fatherism is a euphemism for a political sponsor and political dictator. The problem of god-fatherism came with politics of ethnicity in Nigeria. As the postcolonial Nigerian leaders were taking over from the British, one of the ideologies sold to their followers, was the need to accept some political leaders as political god fathers and leaders of independence. Although, the phenomenon has been going through series of modifications and changes over time, the modus operandi, is that, for a candidate to prosper in politics, the candidate must accept the philosophy of his/her political god fathers, abide by their terms and show absolute loyalty to party manifestos.

It was during the 1980s' period of Nigerian economic recession and the attendant crises the recession generated that the opportunistic ruling elites in Nigeria assumed predominant roles of god fathers. Elites who were able to capture any apparatus of the state and satisfactorily flouted public wealth were accorded much recognition, the consequence of which pulled these actors into the mainstream of Nigerian politics. Increasing economic dependence, that the recession had planted in the nation's political economy thereafter turned out to be a greater opportunity for the opportunistic elites to feed on people's misfortunes. This explains why political god fathers saw, politics as a 'do or die affair'. By the end of the1990s, over fifty percent of Nigerian god fathers were either ex-military rulers or beneficiary of the Nigerian military state(Ake, 1996; Mbaku, 2000; Yagboyaju, 2007). Many of these emerging elites saw the return to civilian rule as another opportunity of raking the resources of the Nigerian state. They consequently planted themselves as political god fathers in the three emerging political parties, the Alliance for Democracy(AD), All People's Party(APP) and the People's Democratic Party(PDP). In the PDP, these political elites had a very large cloud, it was this chance created by the political space that further accelerated patron-clietist politics and politics of pre-bendalism in Nigeria. 


\section{Macrothink}

The adverse effects of this, did not become glaring until during the last regime of President Olusegun Obasanjo 2003-2007. Why was this period, so significant in the political history of Nigeria, and the analysis of money and politics in Nigeria? The answer is not far-fetched. President Olusegun Obasanjo had wanted the extension of his tenure as the President of the Federal Republic of Nigeria. Every activity that would make this vision realistic was put in place. In the process, the President and his Vice, Atiku Abubakar pitched tent, and engaged in verbal war. This political rivalry later degenerated to court cases, many of which the Vice President won in court.

Opposition state governors and politicians who did not support Obasanjo's third term bid faced brick wall from the President. Governor Ladoja of Oyo State, as a result of this impending political uncertainty suffered impeachment from office, although later restated by the Supreme Court. The story of Governor Chris Ngige is sufficed to explain the role of money-bag politics and god fatherism in Nigeria's general elections. Chief Chris Uba was said to have sponsored the election of Dr. Chris Ngige as the Governor of Anambra State. In return for the money spent in prosecuting the election, Chief Chris Uba, was reported to have hammered that his finances must be recouped, and the Governor too must show absolute loyalty to his political backing. These were the features that Governor Chris Ngige lacked. Not too long, an impeachment plot was moved, and eventually the Governor was removed from office. His removal caused some uproar in the state, but this was contained by the Federal Government, an angle where the "god father" was enjoying a stronghold on political power in the state.

In this instance, politics was conceived as a means of livelihood, a source of wealth and an avenue to reap back profits from a business venture. No wonder, some political economists like Ake, Onimode, and Inhovebere regard politics state capture premised on pure business terms. The Nigerian state is more less a "Privatized Entity", a "Business Centre", and an "Industry" where so called "Investors"-the political god fathers must reap their benefits. Political actors, who lacked the required capital to finance their political ambition, most times, have to depend on god fathers, who must have gotten their wealth from long years of expropriation of national resources. Unbundling the state from their hands, has in recent times, been a difficult task.

In contemporary Nigeria, things have not really changed, there is hardly a party where majority votes count in the selection of party candidates or appointment of public office holders. Candidates for political offices are close associates of political god-fathers or political sons of prominent political actors in the society. This is why William Mervin Gumede provides this summary about African political elites:

Most of today's African elite come from the educated political class of the first independence movements, traditional leaders or royalty and were the power-brokers under the colonial system. In some African countries, departing colonial powers deliberately created a small black elite, often from one ethnic group, as part of their divide-and-rule policy. The leaders of African independence movements generally also became the post-independence elite in 
politics as well as business and civil society. They formed a new aristocracy or network, had access to lucrative government jobs and contracts, secured public service promotion and benefited from economic empowerment and affirmative programmes. In those African countries that introduced economic empowerment, affirmative action or indigenization programmes at independence to replace local ownership and representation in property, business and the economy, the beneficiaries were mostly elites from the dominant party.------In some cases, the individuals at the helm of most of Africa's independence movements came from the same ethnic group, military tradition or class or even the same school. Many of these movements actually began as ethnic, regional or culturally based organizations(Gumede, 2010:22).

The breeding of money-bag politics in Africa, political god fatherism, one-party state, patron clientism and the incidences of flawed elections are usually premised on the clandestine activities of these ruling elites. Election that was prosecuted with illegal money or characterized by vote buying, if flawed at a tribunal might pitch the patron against the client. This phenomenon was partly what happened between Governor Chris Ngigie of Anambra State and his then god fathers, who perceived the ousting of Ngige as a share waste of his political investment(Yagboyaju, 2007).

\section{Prospects of Overcoming Money-Bag Politics In Nigeria}

Solutions to the problem of money-bad politics lie in the total transformation of the Nigerian state, massive improvement in the economy that will free most of the electorates from the bondage of poverty. When people are well-fed, and can feed their family, they will be able to make the right choices at the appropriate time. Presently, the quest to involve in politics, is premised on primitive capital accumulation and not on good governance. The revolts in North Africa are lessons for Nigerian leaders and the rest of African regions. When masses outrage rise, the most authouritarian state may not be able to subvert it, thus, it is not enough for us to have good institutions of democracy, the welfare of the voters, must be paramount to the government.

\section{Conclusion}

This paper has extensively considered a number of theories of election with a view of adopting the peripheral political economy. In doing this, it exposed the gains of the various theories but contended that they failed to address the contradictions of the Nigerian political economy. The work explained that the recent experiences of flawed elections in the country is intricately linked to money-bag politics and rent-seeking in the country. The conclusion is that Nigeria leaders need to be sincere to their followers, work on the welfare of the citizens, localize governance and improve the conditions of the economy such an average Nigerian can live comfortably. The presence of the foregoing has a lot of implications for the stability of the country and our democracy.

\section{Recommendations}


The following recommendations emerged from our theoretical discourse:

1. There is a need for the crop of Nigerian leaders to embrace good governance, and improve the conditions of the ordinary people.

2. The Federal Government should establish a National Commission On Electoral Offences with the responsibility of investigating and charging electoral offenders to court.

3. There is a need for government to enforce existing electoral regulations on party finances including campaign programmes.

4. The Federal Government should intensify its political education for the elected leaders and party followers.

5. Anti-corruption agencies need to collaborate with banks and other financial institutions to monitor the movement of cash during elections.

\section{References}

Adegboyega, A. (1981) Why We Struck: The Story of the First Nigerian Coup, Ibadan Evans Publishers

Adetula, Victor A. O.(2006) Money and Politics in Nigeria: An Overview in Adetula, Victor A. O. Money and Politics in Nigeria, DFID

Adetula, Victor, A. O. (2006) "Electoral Act 2006, Civil Society Engagement and the Prospect of Political Finance Reform in Nigeria" in Adetula, Victor A. O.(2006) Money and Politics in Nigeria: An Overview in Adetula, Victor A. O. Money and Politics in Nigeria, DFID

Adisa, W. B.(2010) "Capital Accumulation in a Peripheral State and Corruption in Africa" in Ninalowo, Adebayo M. A. ; Badru, Fatai A. and Akinyemi, Rasheed, An Interdisciplinary Discourse on the Human Condition, Lagos, Faculty of Social Sciences

Ake, Claude (1981) A Political Economy of Africa, New York, Longman Publishers Ake, Claude (1996) Democracy and Development in Africa, Ibadan Spectrum Books

Ake, Claude(2000) The Feasibility of Democracy in Africa, Senegal, CODESRIA

Arrow, Kenneth J. (1963) Social Choice and Individual Values , $2^{\mathrm{ND}}$ Edition, New Haren, CT, Yale University Press

Constitution of the Federal Republic of Nigeria 1999 


\section{Macrothink}

Journal of Public Administration and Governance ISSN 2161-7104 2012, Vol. 2, No. 1

Cunliff-Jones, Peter(2010) “Nigeria's Answer: Indonesia and Nigeria Have Remarkably Similar Histories, in BBC Focus on Africa, Nigeria’s Journey, UK, Sollatek Limited

Ekeh, P. P. (1975) "Colonialism and the Two Publics in Africa: A Theoretical Statement" in Comparative Studies in Society and History, Vol. 17 No.1

Hibbs, D. (1977) "The Political Parties and Macro-Economic Policy": American Political Science Review Vol.71 pp.4

Hibbs, D.(1977) "The Political Parties and Macro-Economic Policy, American Political Science Review, VOL. 71 PP.4

Ihonvbere, Julius (1989) The Political Economy of Crisis and Understanding in Africa: Selected Works of Claude Ake, Lagos, JAD Publications

Iyayi, Festus (2007) "Elections, INEC and the Problems of Mindsets in Nigeria", the Electoral Journal Vol.1 No. 1

Iyayi, Festus (2008) "Elections: INEC and the problems of Mindsets in Nigeria, INEC Electoral Journal, Opeit pp.2.

Joseph, 'Lai (1995) Nigeria: Shadow of a Great Nation, Lagos, Dubeo Press Limited

Kaufman, Daniel and Dininio, Phyllis(2006) "Corruption: A Challenge for Development" in Stapenhurst, Pick ; Jonhston, Niall and Pellizo, Riccardo The Role of Parliament in Curbing Corruption, WBI, Washington D.C. , The World Bank

Mamdani, M. (2004) Citizens and Subject: Contemporary Africa and the Legacy of Late Colonialism, Uganda, Fountain Publishers

Mbaku, J. M. (2000) "Bureaucratic Corruption in Africa: The Futility of Cleanups", Cato Journal Vol.16, No. 1

Mbaku, J. M. 1997. Bureaucratic and Political Corruption in Africa: The Public Choice Perspective, Florida, Krieger Publishing Company

Mbaku, J.M.(1992) 'Bureaucratic Corruption as Rent Seeking Behavior', Konjunkturpolitik(Germany) Vol.71 Nos. 1-2 pp.19-31

Mbaku, J.M.(1995) 'Post Independence Opportunism and Democratization in Africa', Journal of Social, Political and Economic Studies, Vol.20 No.4, pp.405-22

Monfrini, E. (2008) "The Abacha Case" in Mark Peith Recovering Stolen Wealth, Germany, Basel Institute of Governance 
Mungiu-Pippidi, A. (2006) “Corruption: Diagnosis and Treatment”, Journal of Democracy July 2006 Volume 17 November 3

Nigerian Compass(2009)Gov. Mimiko: The Sun Will Continue to Shine: Thousands Attend Swearing-in; Governor Promises Mass Employment, Wednesday Feb. 25, 2009, Lagos, Western Publishing Company Limited.

O'Brien, Robert and Williams, Marc(2004) Global Political Economy: Evolution and Dynamics, New York, Palgrave Macmillan

Onimode, Bade(1989) The IMF, the World Bank and the African Debt, Volume 1, The Economic Impact, ZED Publications

Pfeiffer, Silke (2004) "Vote buying and its Implications for Democracy: Evidence from Latin America" Transparency International (2004) Global Corruption: Report 2004: Special Focus: Political Corruption, London, Pluto Press

Pin-Duschinsky, Michael(2006) "Party Political Funding” in Staphenhunt, Rick, Jonhston, Niall and Pelizzo, Riccardo The Role of Parliament in Curbing Corruption, WBI, Washington D.C.

Robert Pastor (2005) The Role of Electoral Administration in Democratic Transitions: Implications for Policy and Research, Dept. of Political Science, Mary University Atlanta.

Smith, B.C. (2003) Understanding Third World Politics: Theories of Political Change \& Development, New York, Palgrave Macmillan

Transparency International (2004) Global Corruption: Report 2004: Special Focus: Political Corruption, London, Pluto Press

Tullock, G.(1993) Rent-Seeking, Brrokfield, Vermont: Edward Elgar

Walecki, Marcin (2004) "Political Money and Corruption" in Transparency International (2004) Global Corruption: Report 2004: Special Focus: Political Corruption, London, Pluto Press

Wiseman, J.(1990) 'Principles of Political Economy: An Outline Proposal, Illustrated by Application to Fiscal Federalism, Constitutional Political Economy, Vol. 1 No.1 pp 101-124.

Withman, Donald (1983) "Candidate Motivation: A Synthesis of Alternative Theories" American Political Science Review, Vol. 77. No.1 March pp.142.

Yagboyaju,Dhikru Adewale (2007) 'From Clientism and Prebendalism to Godfatherism: The Trajectory of Nigeria's Politics of the Belly" in Aina, Ayandiji D. Corruption and the Challenge of Human Development, Ogun State, School of Man 